Dr. N. Gilboa comments :

Thank you for allowing me to comment on the letter from Dr. Wharton. We performed the study of CPK levels in randomly selected normal newborns for the following reasons. (1) The increased interest in the subject due to the possibility of using CPK in newborn screening for Duchenne muscular dystrophy (DMD) (Zellweger and Antonik, 1975). (2) Although several previous investigations dealt with CPK in normal newborns, only a few, as noted by Wharton et al. (1971), have given sufficient clinical correlation. (3) The inconclusiveness of the findings regarding the effect of the perinatal factors on the CPK activity (Ballario and Pavesio, 1969; Bodensteiner and Zellweger, 1971; Rudolph and Gross, 1966). (4) Lack of consistent data regarding the difference of CPK activity in simultaneously obtained cord, venous, and capillary blood in newborns (Bodensteiner and Zellweger, 1970). (5) The large number of laboratory techniques with widely varying degrees of reliability used in the previous works. This poses a significant problem in standardization of CPK. Our study was preformed using the Rosalki (1967) method which is one of the most widely used and most reliable methods (Dubowitz, 1976a).

With the exception of 2 cases reported by Heyck et al. (1966) and Dubowitz (1976b), the CPK level in newborns affected or carriers of DMD is unknown. Some of the normal newborns have CPK levels up to 10 times the upper limit of normal (Gilboa and Swanson, 1976). These levels are not significantly different from the CPK level found by Dubowitz (1976b) in the affected male on the third day of life. We also showed that while the mean CPK level was still raised after 4 days of life, it was well within the normal range in all infants examined at age 6 to 10 weeks. Thus, unless proved to the contrary, it is very possible that the CPK of an affected male, and particularly of a carrier, may be 'lost' in the upper limits of normal if obtained within the first few days of life.

I agree with Dr. Wharton that a prospective study of CPK in newborns from families with a known history of DMD is very important and should be preferable to initiation of a newborn screening programme. However, if such a programme is initiated the study of CPK should be delayed for a few weeks, and certainly for at least one week after birth, in order to minimize the risk of false-positive results.

Finally, I would like to note that according to the Rosalki method (Rosalki, 1967) used in our study, the determination of the CPK was performed in serum and not in plasma, as referred to by Dr. Wharton.

NISAN GILBOA

University of Colorado Medical Center, B. F. Stolinsky Research Laboratories, Department of Pediatrics, Denver, Colorado.

REFERENCES

Ballario, R., and Pavesio, D. (1969). Considerazioni sul significato della creatinfosfochinasi serica nel neonato. Minerva Pediatrica, 21, 253.

Bodensteiner, J., and Zellweger, H. (1970). Utilization of capillary blood for serum enzyme analysis. Helvetica Paediatrica Acta, 25, 397.
Bodensteiner, J., and Zellweger, H. (1971). Creatine phosphokinase in normal neonates and young infants. fournal of Laboratory and Clinical Medicine, 77, 853.

Chadd, M., Gray, O. P., Saunders, R. A., and Jones, R. T. (1966). Serum aldolase and phosphocreatine kinase in umbilical cord blood. Fournal of Clinical Pathology, 19, 600.

Dubowitz, V. (1976a). Screening for Duchenne muscular dystrophy. Archives of Disease in Childhood, 51, 249.

Dubowitz, V. (1976b). Genetic miscounselling in muscular dystrophy. Archives of Disease in Childhood, 51, 325.

Gilboa, N. and Swanson, J. R. (1976). Serum creatine phosphokinase in normal newborns. Archives of Disease in Childhood, 51, 283.

Griffiths, P. D. (1968). The activity of ATP: creatine phosphotransferase (E.C.2.7.3.2.) in umbilical cord blood. Clinica Chimica Acta, 20, 465.

Heyck, H., Laudahn, G., and Carsten, P. M. (1966). Enzymaktivitätsbestimmungen bei Dystrophia musculorum progressiva. Klinische Wochenschrift, 44, 695.

Natoli, G., Lapi, A. S., Mancini, G., Gerlini, G., and Natoli, V. (1966). Le ultramicroanalisi di laboratorio nella practica pediatrica. III. Dosaggio spettrofotometrico di alcune attivita enzimatiche sieriche e valori normali nelli infanzia. Archivio Italiano di Pediatria e Puericoltura, 24, 373.

Rosalki, S. B. (1967). An improved procedure for serum creatinine phosphokinase determination. Fournal of Laboratory and Clinical Medicine, 69, 696.

Rudolph, N., and Gross, R. T. (1966). Creatine phosphokinase activity in serum of newborn infants as an indicator of fetal trauma during birth. Pediatrics, 38, 1039.

Sitzmann, F. C. (1967). Kreatinphosphokinase-Aktivität im Serum bei Säuglingen und Kleinkindern. Zeitschrift für Kinderheilkunde, 99, 48.

Verri, B., Macagno, F., and Corazza, G. (1966). La creatinfosfochinasi (CPK) nelle varie età pediatriche. Minerva Pediatrica, $18,2256$.

Wharton, B. A., Bassi, U., Gough, G., and Williams A. (1971), Clinical value of plasma creatine kinase and uric acid levels during first week of life. Archives of Disease in Childhood, 46, 356.

Zellweger, H., and Antonik, A. (1975). Newborn screening for Duchenne muscular dystrophy. Pediatrics, 55, 30.

\section{Rapid assessment of gestational age at birth}

Sir,

We read with interest the article of Parkin, Hey, and Clowes (1976) on this subject based on four superficial criteria, in which they obtained $95 \%$ confidence limits of \pm 15 days on a curvilinear regression. Since a comprehensive computer analysis of our original data (Dubowitz, Dubowitz, and Goldberg, 1970) was unable to yield any smaller combination of criteria approaching the reliability of the total group (L.M.S. Dubowitz, and R. A. Dixon, unpublished observations, 1973), their results were somewhat surprising to us. We thought that one possible reason for the discrepancy might have been a difference in our respective samples. Theirs had a fairly normal distribution with 36 of their 314 term infants $(11 \%)$ being small-for-dates, whereas in our total series of 166 infants 49 were small-for-dates (about $30 \%$ ). Moreover, there were only 46 preterm infants in their total series of $392(11 \%)$ whereas in ours there were 53 (about 30\%).

We have accordingly reanalysed our original data for the four criteria selected by Parkin et al. with particular reference to the error of prediction in the small-for-dates and appropriate-for-dates groups. On a linear regres- 